\title{
A figuração do longínquo: natureza, fotografia e sujeitos no Brasil nas fronteiras do século XIX
}

Brizuela, Natalia. Fotografia e império: paisagens para um Brasil moderno. Tradução de Marcos Bagno. Sáo Paulo: Companhia das Letras; Instituto Moreira Salles, 2012.

A obra Fotografia e império: paisagens para um Brasil moderno conta as histórias controversas da formação da nação, real ou imaginada, representadas nas visualidades e nas invisibilidades das fotografias imperiais e republicanas. Balizas de um longo e intenso processo de figuraçáo e de invenção de um país, cuja complexa inserção na modernidade traz em si o índice das distâncias, do longínquo no tempo ou no espaço.

Como as fotografias que apresenta ao início de cada capítulo, a professora da Universidade de Berkeley, Natália Brizuela, natural da Argentina, realiza a arte mimética de registrar experiências históricas. Por meio de um texto elegante e bem elaborado, deixa na memória do leitor três grandes imagem-força: a floresta, a vendedora negra e o monge sertanejo morto. Seriam estas as três grandes imagens da constituição de nossa identidade nacional às avessas? Seriam elas as imagens que buscamos para entender nossa história? Ou seriam as ima-

\author{
Janaina Zito Losada*
}

gens das quais fugimos na leitura da nação? Seriam elas parte de nosso desencantamento ou re-encantamento com o próprio passado e os seus fragmentos luminares? Essas questôes feitas a partir da leitura da obra instigam ao questionamento do projeto da autora sobre a figuração dos territórios, dos espaços e dos sujeitos, objetos ao mesmo tempo da história da representação e da história da cultura.

A fotografia constitui para ela o elemento fundamental da nação. Ao fotografar a natureza, o indivíduo permitia um re-encantamento com o mundo natural, há muito perdido pelo sujeito moderno. Mas a fotografia constitui parte do arco de processos de construçáo das imagens da modernidade, onde figuram também litografias, gravuras, óleos, aquarelas etc.

$\mathrm{Na}$ apresentação da obra, escrita por Flora Sussekind, destaca-se o exercício deste re-encantamento através da seleçáo de Brizuela ao apresentar a análise da obra Zoophonia, de Hercule Florence. Como os pontos de fuga das telas da arte moderna, a autora acrescenta um elemento que, ao desconcertar o leitor, conduz o seu olhar. Em uma obra sobre imagens esse desconforto vem da exploração das representaçóes dos sons da

lândia — campus Pontal. Ituiutaba, MG, Brasil. E-mail: janainalosada@pontal.ufu.br. 
natureza. Tudo na obra é fotografia, mesmo quando é som!

Desde o desejo do grandioso e da imaginação poética do sublime até a real crueza da guerra e do assassinato, a autora apresenta um diorama no qual o leitor desavisado pode sentir a vertigem provocada pela sensação da fragmentação e da drástica mudança de cenário. Acostumados com as altas tecnologias televisivas e as realidades virtuais e holográficas, estamos a pensar as fotografias, no campo das ciências humanas, de forma geral e, da história, de forma particular, um desafio que tem sempre como marca a ideia da origem. Trata-se da origem de nossos desejos de imortalizar a nossa própria existência, de registrar o vivido, de divulgar um determinado enquadramento de nós mesmos, nossas experiências, nossas sociedades e nossos tempos. A história das fotografias é essencial para o entendimento dessas vontades que nos legaram os indivíduos do século XIX. Vontade de ver, emoldurar, enquadrar, registrar e expor.

A obra contrasta e sobrepóe a imaginação e as representaçóes do espaço, do tempo e dos outros. Organizado em quatro capítulos, o livro versa sobre as experiências de homens e mulheres que viveram os limites dos séculos XIX e XX e as experiências com a jovem arte da fotografia. O seu arco temporal engloba o império de d. Pedro II (18401889) e a guerra de Canudos (1896/97). A linha explicativa adotada se dá pela autorrepresentação do império nas fotografias selecionadas. Esta história mescla fotografias de paisagem e de retratos, partituras musicais, mapas, descriçóes; falas sobre o mundo e os espaços vazios, os distantes territórios e as suas representaçóes; apresenta os fotógrafos, os viajantes, os cientistas e o impacto neles causado pela luz e pelo calor dos trópicos. A iluminação excessiva privilegiava o olhar fotográfico; além dela havia o exótico na forma de homens e feras. $\mathrm{O}$ exótico que foi também o da fome e o da guerra. Aquele que se transformou em trágico na exposição da própria tragédia. As fotografias constituiriam os luminares de uma época, os objetos únicos de figuração de uma realidade distante que podem ser encontradas hoje em arquivos e museus, em exposição ou guardadas em baús ou em antigos álbuns. Aqui, as encontramos na trama do texto de Brizuela, que se destaca por trazer o trágico, muitas vezes silenciado pela historiografia.

No capítulo 1, "Para cada dia um mapa: d. Pedro II, os românticos, o IHGB e a visualização do Brasil", a autora destaca a importância da imaginação geográfica, da arte cartográfica e do uso da fotografia de paisagem na constituição do Atlas do Brasil. Obra cujos enquadramentos e recortes da paisagem constituíram uma memória imagética do Brasil que muito fomentou os referenciais das identidades nacionais. Para tanto, a autora lança mão de fotografias e litografias de Vitor Frond e Marc Ferrez, que enquadram uma natureza idílica, descrevem montanhas e florestas, envoltas em névoas, mares que refletem as praias, jardins, baías e palmeiras que denotam grandiosidade, que colocam em tela o selvagem e o domesticado, o intocado, o reproduzido. A missão romântica muito difundida no interior dos quadros do Instituto Histórico e Geográfi- 
co Brasileiro buscou dar à vista do segundo império um país através da sistematização e recuperaçáo da memória. $\mathrm{O}$ pitoresco como forma de inscrição no mundo, essencial para a retórica histórica, comprovada pelos diários e fotografias, codificada nos registros das experiências, tornou visíveis o tropos da viagem, da saudade e do naturalista.

No capítulo 2, "O som da natureza, ou escrevendo com luz nos trópicos: Hercule Florence", a autora versa sobre os elementos da tropicalidade, promovendo um inventário sonoro a partir do texto Zoophonia, de Florence. A natureza descrita com a requintada maestria dos sons que, bem inventariados, ajudariam a configurar as paisagens, registrando a vida, seus "sentimentos e emoçôes", mas seria possível registrar os sentimentos dos animais traduzindo seus urros e pios em uma pauta musical? Seria o inventário de Florence mais que um empreendimento fracassado e um tanto pitoresco de um inventor diletante? A autora aponta que tal empreendimento possibilitou uma forma de reencantamento com a natureza. Ao registrar os sons emitidos pelos animais em escalas musicais, com seus muitos graves e agudos, Florence lhes dá sentimentos humanos - os cacarejares eram alegres, alguns pios eram melancólicos, a gaivota gritava ansiosa e o gorjeio do jaú ressaltava o silêncio das trevas. Publicado em 1876, na Revista do Instituto Histórico e Geográfico Brasileiro como uma contribuição anônima, o documento não passou despercebido pela historiografia. Em Brizuela ele vem compor o quadro da cartografia simbólica e visual dos trópicos, o mapa de notas mínimas e semínimas em $m i, f a$, sol, si, dó pelo qual o império deixa ver os seus animais, os seus indivíduos e a si mesmo. A história dos trópicos impressa pelo som e pela luz, ou pela fotografia e pela música, faz lembrar a estética arquetípica de Goethe e os sons dos quadros da natureza de Humboldt que tanto marcaram o romantismo made in Brazil.

No terceiro capítulo, "Lembranças da raça", a autora entra no mundo dos retratos e nas formas de visualização dos tipos locais, indígenas, negros, mestiços, crianças. Através das lentes obsessivas dos naturalistas europeus, entre eles Louis Agassiz, e do seu ímpeto científico pela coleção de exemplares do mundo, sejam cenas, crânios ou redes de pesca, as ciências naturais mesclavam-se ao missionarismo romântico. Desta forma conferiram certo sentido ao mundo, produzindo uma imensa gama de materiais pictóricos, aquarelas, óleos e, por fim, fotografias. Ora reproduzindo as tradiçóes de visualidade existentes em seu tempo, ora criando novas formas de a sociedade se relacionar consigo mesma, a captura das imagens buscava realizar um mapeamento dos indivíduos, dos referenciais raciais, da tipificação das atividades e dos indivíduos, dos cidadãos e dos escravos, inventariando diferenças e estranhamentos, medos e saberes.

No último capítulo da obra, "A fotografia às margens da história: os sertôes", a autora explora as terras arruinadas pelas guerras e pelos massacres. As ruínas e as feras selvagens, o deserto de Canudos, o clima sufocante retratado no álbum do fotógrafo Flávio Barros, que acompanhou uma das expediçóes do exército àquelas terras 
sertanejas. Nele, o destaque é o vazio, é a imagem do campo de batalha, da natureza decaída, profanada, da morte em um território longínquo que se impóe à nação. Faz com que as imagens de mulheres e crianças sertanejas famélicas, à beira do assassinato, figurem de forma incômoda no panorama da modernidade brasílica. A recém-república se consolidou pela força de vencer em Canudos, a morte dos sertanejos foi o símbolo da morte da monarquia. Para a autora, a última batalha de Canudos foi o confronto final entre civilização e barbárie. As fotografias de Barros e o relato de Euclides da Cunha falam dessas mortes e do espetáculo trágico que ciência, artes e técnica registraram para a posteridade. A melancolia informada pela experiência com o território e com os eventos históricos é atravessada pelo terror, pelo assombro, pela catástrofe. Na leitura de Brizuela, fantasmas pré-modernos de vários tipos figuram no imaginário euclidiano.

As duas fotografias finais da obra exemplificam as duas tropicalidades presentes no pensamento oitocentista e novecentista nacional e em suas autorrepresentaçóes. Antonio Conselheiro, morto em meio a ruínas de um chão agreste, e o velho d. Pedro II em estúdio, envolto por uma mata cenográfica, são exemplares; registram o que, em meados do século XX, já não existia mais. São a lembrança triste e, por vezes, trágica de um país no passado. Assim, a República marcava a sua originalidade, se construía das cinzas de uma modernidade imperial e esmagava todo o frescor que o passado pudesse ter tido.

A formulação literária e a composição dos ensaios trazem leveza à história conta- da. Mas, é a pertinência nas leituras sobre a construção da nação e sobre as ideias produzidas e veiculadas no império e no início da república que marca a obra. A autora estuda as visibilidades de uma época de transição, cenas de um país no passado, foco de disputas imagéticas e simbólicas que desde aqueles tempos atravessam os indivíduos, os poderes e as sociedades. No mundo contemporâneo, os possíveis simulacros das imagens já foram desvendados, mas as fotografias dos passados continuam a instigar reflexóes sobre a pitoresca modernidade que essas geraçóes de homens legaram ao futuro.

Para Jacques Aumont (2004) a fotografia, ponto de encontro entre a pintura e o cinema, traz em si três aspectos que são comuns a essas três artes: o impalpável (luz), o irrepresentável (técnica) e o fugidio (tempo). Imposiçóes e limites que delinearam as épocas nas quais as imagens foram produzidas. Resgato aqui esses elementos para ler a história das imagens de Brizuela. O impalpável, que pode ser percebido nos cartóes de visita e na taxonomia dos indivíduos que esses artefatos promovem, imobilizando os sujeitos em suvenires turísticos. O irrepresentável, sugerido nos ruídos e nas memórias fragmentadas das tensóes cotidianas e dos embates experimentados em uma sociedade tão desigual e violenta. O fugidio, que na fotografia é percebido no deslocamento do foco, que sugere imagens em borróes e manchas, que destacam o particular e único momento que já não existe e assim se deixa marcar no tempo que já não é.

$\mathrm{O}$ desejo pela coleção de imagens e as histórias das quais elas são artefatos mes- 
clam esses universos e produzem uma expo- te e conta, por meio das imagens, a história sição do país para si mesmo e para os outros. que a autora narrou anteriormente por meio Tal exposição fixa-se nas leituras da história do texto. É uma obra que merece figurar nas e das identidades nacionais. A apresentaçáo estantes e bibliotecas dos amantes e estudiodas fotografias, ao final da obra, traz requin- sos da fotografia e da história no Brasil. 